\title{
Forest Structure of a Tropical Rain Forest at Lambir, Sarawak with Special Reference to the Dependency of its Physiognomic Dimensions on Topography
}

\author{
Takuo YamaKuRA, Mamoru KANZAKI Department of Biology, Faculty of Science, Osaka City \\ University, Sumiyoshi-ku, Osaka 558, Japan \\ Akira ITOH University Forest, Faculty of Agriculture, Ehime University, Ohinotyo, Matsuyamashi \\ 790-01, Japan \\ Tatsuhiro OHKUBO Department of Forestry, Faculty of Agriculture, Utsunomiya University, Minemachi, \\ Utsunomiya 321, Japan \\ Kazuhiko OGINO Department of Forestry, Faculty of Agriculture, Ehime University, Matsuyama 790, Japan \\ Ernest CHAI O. K. Silviculture Research Office, Forest Department, 96000 Sibu, Sarawak, East Malaysia \\ Hua Seng LEE Forest Department Headquarters, Forest Department, Petra Jaya, 93660 Kuching, Sarawak, \\ East Malaysia \\ Peter Shaw AsHTon Harvard Institute for International Development, Harvard University, One Eliot \\ Street, Cambridge, Massachusetts 02138, USA
}

\begin{abstract}
The stand structure of a mixed dipterocarp forest was analyzed by using the data obtained from a fifty-two hectare research plot at the Lambir National Park, Miri, Sarawak, East Malaysia. The range of data analyses in the present study was confined to the topics of physiognomy while awaiting species identification data. The forest height evaluated by a height curve model of a hyperbolic equation was the tallest in Lambir among three research sites, Barro Colorado Island in Panama, Pasoh in West Malaysia, and Lambir in East Malaysia. By dividing the 52 ha plot into 1300 stands of $20 \mathrm{~m} \times 20 \mathrm{~m}$, the physiognomic dimensions, such as the biomass, tree density, maximum $\mathrm{dbh}$, and basal area per stand, were calculated and their dependency on topography was statistically tested. The results of statistical tests suggest that the significant differences of physiognomic dimensions between stands are marked by different topographic conditions in terms of slope altitudes, angles, directions, and convexity degrees. The correlated change in physiognomic dimensions and local topography implies the dependency of the relative occurrence of three growth phases (gap, building, and mature phases) in the forest growth cycle upon topography. The size structure of the stands was analyzed by using dbh data and by assuming the exponential distribution of dbh. The stands were characterized by stratified subpopulations, whose total number per stand was in a range between two and seven. The variation in the number of sub-populations per stand corresponded well to the altitude difference between stands, suggesting correlated gradients in the forest stratification, forest growth cycle, and topography. All these results suggest the presence of predictable change of the huge and complex architecture of the rain forest at Lambir in relation to topography or environmental conditions such as soil and water. In these respects, the results seem to be favored by an equilibrium hypothesis rather than non-equilibrium hypothesis as a working mechanism of tropical biodiversity, though floristic composition can be independent from physiognomic dimensions.
\end{abstract}

Key Words: Biodiversity / Biomass / Density dependency / Environment / Equilibrium / Large-scale / Long-term / Structure / Non-equilibrium / Physiognomy / Stratification / Sarawak / Tropical rain forest / Topography

A long-term and large-scale research of a tropical rain forest was recently initiated on a hilly slope at the Lambir National Park, Sarawak, East Malaysia. The plan involves establishment of a 52 ha research plot for multi-purpose use in research on forest conservation, park management, etc. (Yamakura et al., 1995a). In a preceding study (Yamakura et al., 1995b), we analyzed the detailed structure of the topography of our plot, which was constructed under a tall canopy of mixed forest with various dipterocarp dominants. The altitude range between the highest and lowest points in the 
plot was ca. $150 \mathrm{~m}$, reflecting on steep topography at Lambir. Hypsographic curves suggested that the topography of our plot at Lambir was more hilly and complex compared with other 50 ha research plots at Pasoh in Peninsula Malaysia (Manokaran et al., 1990) and Barro Colorado Island (BCI) in Panama (Hubbell \& Foster, 1983). Four topographic variables, altitude, angle and direction of slope, and convexity indices of slopes, were calculated for $1,300,20 \mathrm{~m} \times 20 \mathrm{~m}$ quadrats within the plot. The statistics of these variables also clarified the steep and complex topography of the plot (Yamakura et al., 1995b).

The first forest inventory record from a large-scale research plot should offer an unprecedented opportunity for understanding both the community structure of the species as a whole and the population structure of single species. The structural aspects of species and floras are, however, ignored in this study, owing to incomplete species identification at present 1995 . The interesting topic of the existence of many rare species is also ignored for the same reason. Therefore, the major forest structural variables handled in this study are confined to several physiognomic dimensions, such as tree height, stem diameter, stand biomass, etc. These variables are analyzed with reference to local variations in topography within the plot, and by using the aforementioned results of the preceding study (Yamakura et al., 1995b). The results of the analyses in the present study will offer an empirical basis for discerning the relative applicability of two contrasting ecological hypotheses, the equilibrium and non-equilibrium hypotheses (Hubbell and Foster, 1986), to the structural variation in a tropical rain forest at Lambir.

\section{METHODS}

Our research was carried out on steep slopes in the Lambir National Park with an approximate latitude of $4^{\circ} \mathrm{N}$ and longitude of $114^{\circ} \mathrm{E}$, in Sarawak, Malaysia. Most of the park area is covered by undisturbed original vegetation, the mixed dipterocarp forest common in the lowlands in Borneo. Our study site was chosen so as to represent this mixed dipterocarp forest. The general descriptions of the study site with respect to this park history, climate, physiography, geology, soil, and vegetation are omitted here, since they were given in a preceding paper (Yamakura et al., 1995b).

The land survey for plot demarcation was initiated in November 1990 and finished in March 1992 (cf. Chai et al., 1994; Yamakura et al., 1995a). It was followed by the census of trees or forest inventory, which was initiated in August 1991 and finished in September 1993. A total of 358,905 trees $1.0 \mathrm{~cm}$ and greater in stem diameter at breast height $(\mathrm{dbh})$ was individually labeled, mapped, identified to species, and measured by dbh. Further details of the inventory work and data management were described in a separate paper (Chai et al., in press). The 52 ha plot was divided into 1,300 quadrats of $20 \mathrm{~m} \times 20 \mathrm{~m}$ in area, and the quadrats were used as a unit of data analyses in present paper. Besides this forest inventory work, 112 trees were sampled within the 52 ha plot and their tree height was measured for the determination of a tree height curve indispensable for stand biomass estimation.

\section{RESULTS}

\section{Forest architecture}

Relation between dbh and tree height was approximated by a height curve model consisting of a hyperbolic equation of height to dbh (Ogawa et al., 1965), i.e.

$$
\frac{1}{H}=\frac{1}{A D}+\frac{1}{H^{*}}
$$



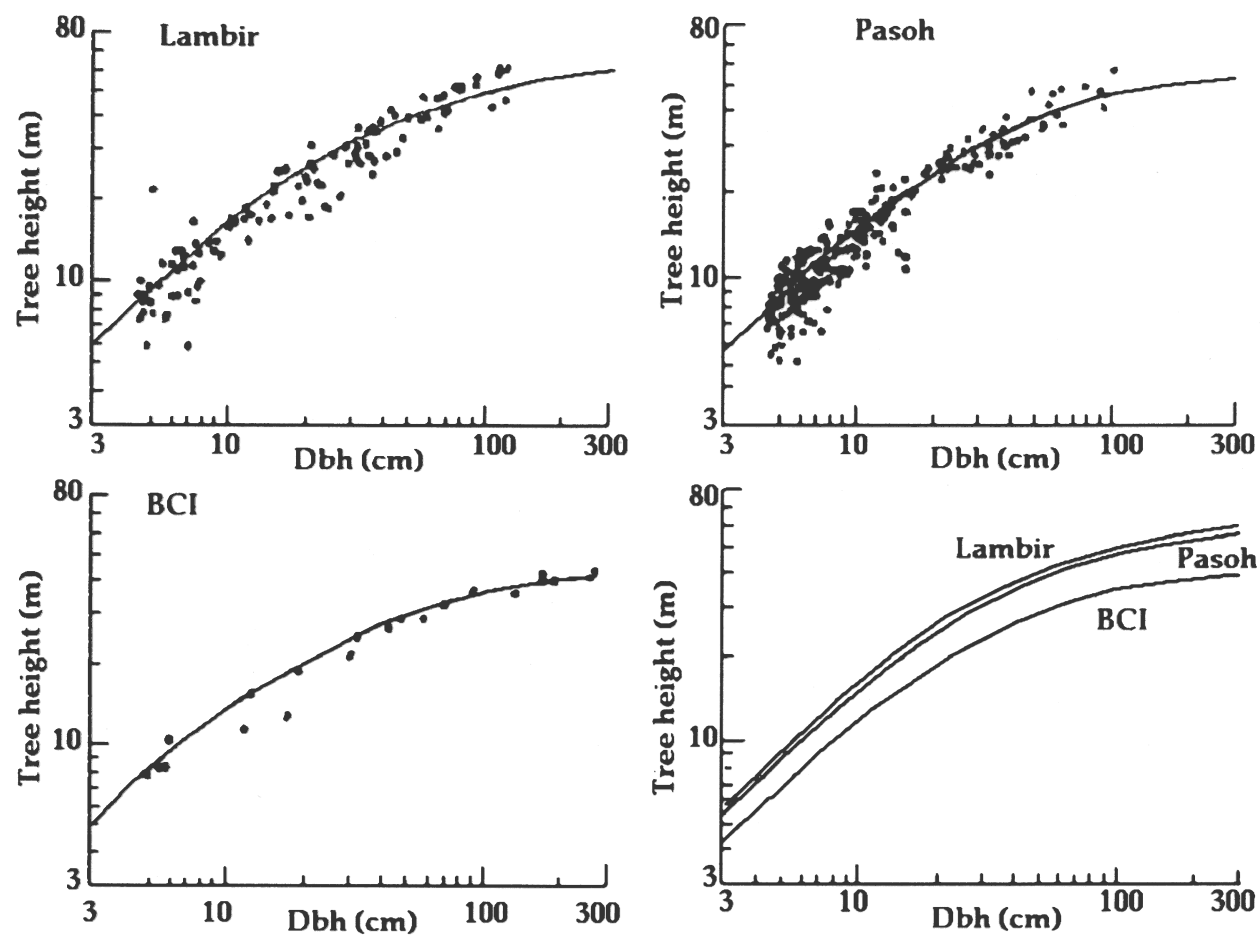

Fig. 1. Tree height curves at three research sites, Lambir, Pasoh, Barro Colorado Island (BCI). Height curves consist of a hyperbolic equation of tree height $(H, m)$ to stem diameter at breast height ( $\mathrm{dbh}=D, \mathrm{~cm})$ and are written in the form, $1 / H=1 /(A D)+1 / H^{\circ}$, with coefficients $A$ and $H^{*}$ specific to the forest. Closed circles represent observed values.

where $H$ is tree height in $\mathrm{m}, D$ is dbh in $\mathrm{cm}$, and $A$ and $H^{*}$ are coefficients specific to a forest. The coefficient $A$ was highly correlated with the biomass density or forest biomass divided by $H^{*}$. The other coefficient, $H^{*}$, stands for the possible maximum tree height specific to the forest (Ogawa et al, 1965; Ogawa, 1969; Kira \& Ogawa, 1971). The coefficients, $A$ and $H^{*}$, estimated from 112 sample trees by the least squares method were $2.162 \mathrm{~m} / \mathrm{cm}$ and $63.0 \mathrm{~m}$, respectively (Fig. 1A). The maximum tree height of $61.0 \mathrm{~m}$ was recorded from a tree of Shorea inappendiculata $116.5 \mathrm{~cm}$ in dbh. Trees over $70 \mathrm{~m}$ in height appear to be sparsely distributed in the plot, though their height measurements were difficult owing to the dense canopy at the lower forest stratum. The estimates of $A$ and $H^{*}$ at Lambir were greater than those at $\mathrm{BCI}\left(A=1.64 \mathrm{~m} / \mathrm{cm}, H^{*}=42.8 \mathrm{~m}\right.$; this study; Fig. 1$)$ and Pasoh $(A=2.0$ $\mathrm{m} / \mathrm{cm}, H^{*}=61.0 \mathrm{~m}$; Kato, Tadaki, \& Ogawa, 1978; Fig. 1), suggesting more dense biomass packing and taller forest architecture of the Lambir rain forest. The differences of two coefficients, $A$ and $H^{*}$, between Pasoh and Lambir were insignificant (cf. Fig.1). The coefficients at BCI were statistically different from those at Pasoh and BCI, respectively $(\mathrm{p}<0.05)$.

According to Ogawa's study (1969) in some Southeast Asian forests, the coefficient $A$ tends to decrease as the other coefficient $H^{*}$ increases, since biomass density is highly correlated with $A$ and decreases with an increase of forest height that is correlative with $H^{*}$. Therefore, the positive correlation between $A$ and $H^{*}$ at three sites was an unusual example in coefficient changes so far known through several preceding studies in tropical Asia. However, if biomass density and forest height increase along environmental gradients, the positive relation between $A$ and $H^{*}$ is possible.

The differences of tree height curves among three sites seemed to coincide well with the mean duration of dry months in a year. The seasonal rhythm of rainfall at BCI is characterized by a long and 


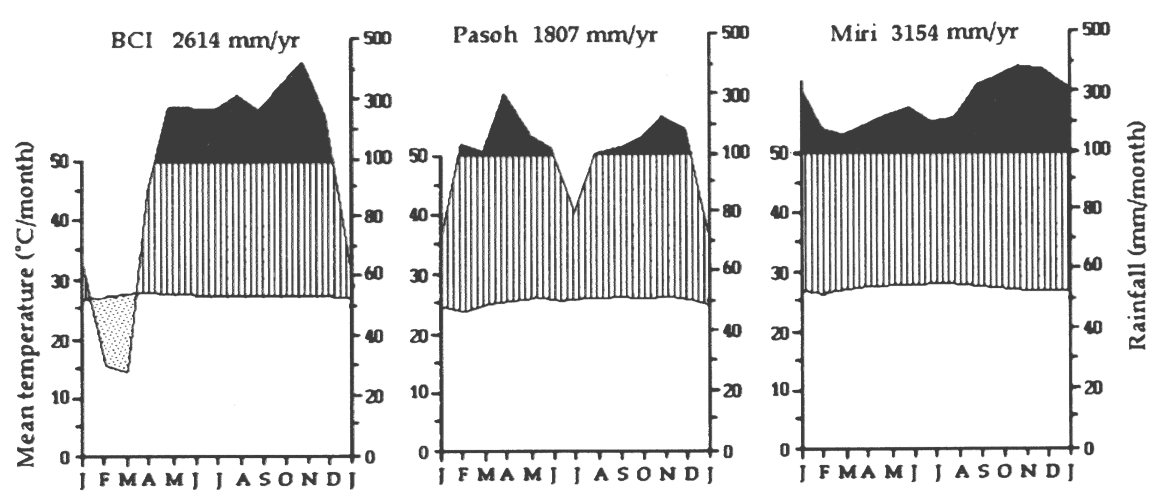

Fig. 2. Climate diagrams at three research sites. Authorities of the climatic data are Windsor (1990) for BCI, Kira (1978) for Pasoh, and Kurashima et al. (1964) and Department of Civil Aviation and Meteorological Services, British Borneo Territories (1961) for Lambir.

clear dry spell, which starts in late December or early January, continues ca. 18 weeks, and ends around April (Windsor, 1990; Fig. 2). The rainfall pattern in the tropics coincides well with the shifts of the Intertropical Convergence Zone (ITCZ) driven by the effects of the changing zenithal position of the sun, in general. At Pasoh, the seasonal rainfall rhythm has two rainfall peaks around April and November, and two short dry periods interrupting the everwet climate around February and July, respectively. A dry spell about one month in July with rainfall a little less than $100 \mathrm{~mm} / \mathrm{month}$ is clearly recognizable in the climate diagram in Fig. 2. The rainfall at Lambir exceeds $100 \mathrm{~mm}$ in all the months of a year without showing clear dry seasons (Fig. 2). Thus, the climate at Lambir is the wettest among the three sites.

Soil nutrients are important factors influencing height growth of forest trees in some Southeast Asian forests without severe droughts (Yamakura et al., 1989; Ashton \& Hall, 1992). The soil chemical properties at BCI seemed to be the richest in nutrients among three sites, since the soil at $\mathrm{BCI}$ is indirectly derived from basaltic ash. The accumulation of nutrients in mineral soil $0-70 \mathrm{~cm}$ soil depth at Lambir was compared with that at Pasoh by Katagiri (1992). The storage of total nitrogen was 5.13 ton/ha at Lambir and 6.75 at Pasoh. The difference of nitrogen accumulation between two sites is rather small. The amount of exchangeable phosphorus was $228 \mathrm{~kg} / \mathrm{ha}$ at Lambir and $46 \mathrm{~kg} / \mathrm{ha}$ at Pasoh. The stocks of three exchangeable cations, potassium, magnesium and calcium were 395, 573 and $510 \mathrm{~kg} / \mathrm{ha}$, respectively, at Lambir, and were 395,112 and $299 \mathrm{~kg} / \mathrm{ha}$, respectively, at Pasoh. Thus the soil at Lambir is richer than that at Pasoh in terms of phosphorus, magnesium, and calcium accumulation. Yoda \& Kira (1982) also described the poor soils and rapid turn over rates of nutrients at Pasoh by comparing the accumulation of exchangeable cations among five tropical forests of the world. Therefore, soil nutrients appear to be important for the explanation of differences of forest height between Lambir and Pasoh. However, the effect of soil nutrients on tree height growth may not be straightforward, if we compare tree height among BCI, Pasoh, and Lambir because the soil at BCI is expected to be nutrient rich as already described.

\section{Huge stand biomass and its big local variations}

Several physiognomic dimensions were calculated for each of 1300 quadrats, which are tentatively designated as stands in the present study. The calculated dimensions were tree density, maximum dbh, basal area, and aboveground biomass. A summary of the statistics of these dimensions is given in Table 1. Similar statistics were also given in a separate paper by one of us (Chai et al., in press). 
Table 1. Basic statistics of forest physiognomic dimensions in 1,300 stands $20 \mathrm{~m} \times 20 \mathrm{~m}$ in area.

\begin{tabular}{|c|c|c|c|c|c|c|c|c|}
\hline $\begin{array}{c}\text { Physiognomic } \\
\text { variables }\end{array}$ & $\begin{array}{c}\text { No. of } \\
\text { data }\end{array}$ & Minimum & Maximum & Mean & S.E. & S.D. & Skewness & Kurtosis \\
\hline Maximum dbh(cm) & 1,300 & 8.9 & 194.2 & 71.0 & 0.705 & 25.4 & 0.552 & 0.581 \\
\hline $\begin{array}{l}\text { Density } \\
\text { (/stand) }\end{array}$ & 1,300 & 95.0 & 592.0 & 276.1 & 1.860 & 67.1 & 0.657 & 1.186 \\
\hline $\begin{array}{l}\text { Aboveground } \\
\text { biomass (ton / ha) }\end{array}$ & 1,300 & 9.0 & 1826.1 & 520.2 & 7.860 & 283.4 & 0.860 & 1.030 \\
\hline Basal area $\left(\mathrm{m}^{2} / \mathrm{ha}\right)$ & 1,300 & 2.2 & 124.5 & 42.8 & 0.502 & 18.1 & 0.586 & 0.370 \\
\hline $\begin{array}{l}\text { Number of subpopu- } \\
\text { lations (/stand) }\end{array}$ & 1,300 & 2.0 & 7.0 & 4.3 & 0.023 & 0.825 & -0.438 & 0.025 \\
\hline
\end{tabular}

The number of sub-populations was counted by stratifying a whole sample population of a stand partial into populations, as described later in the text (for details, see the text).

Stand biomass in Table 1 represents aboveground biomass (excluding roots) and was estimated by the allometry method (Research Group on Forest Productivity, 1960; Ogawa \& Kira, 1977). The allometric relations were obtained by harvesting sample trees in the mixed dipterocarp forest with Shorea laevis Ridl. dominant at Sebulu, Kutai District, East Kalimantan, Indonesia (Yamakura et al., 1986). These allometry equations are reproduced here by the following empirical equations,

$$
\begin{aligned}
& \mathrm{W}_{\mathrm{S}}=2.903 \times 10^{-2}\left(\mathrm{D}^{2} \mathrm{H}\right)^{0.9813,} \\
& \mathrm{~W}_{\mathrm{B}}=0.1172 \times \mathrm{W}_{\mathrm{S}}^{1.059}, \\
& \mathrm{~W}_{\mathrm{L}}=9.146 \times 10^{-2}\left\{\mathrm{~W}_{\mathrm{S}}+\mathrm{W}_{\mathrm{B}}\right\}^{0.7266},
\end{aligned}
$$

where $D$ is dbh in $\mathrm{cm}, H$ is tree height in $\mathrm{m}, W_{\mathrm{S}}$ is stem dry weight in $\mathrm{kg}, W_{\mathrm{B}}$ is branch dry weight in $\mathrm{kg}$, and $W_{\mathrm{L}}$ is leaf dry weight in $\mathrm{kg}$ of an individual tree. Tree height $H$ was tentatively estimated from dbh or $D$ by using Eq. (1) with coefficients, $A=2.162 \mathrm{~m} / \mathrm{cm}$ and $H^{*}=63 \mathrm{~m}$, as already described. Therefore, all the dimensions in biomass computation were estimated by dbh without measuring the other dimensions. The variance statistics of different physiognomic dimensions in Table 1 clearly indicate the big local variations of forest architecture within the plot, as shown by an example of the spatial distribution of biomass per quadrat or stand in the plot (Fig. 3). The spatial

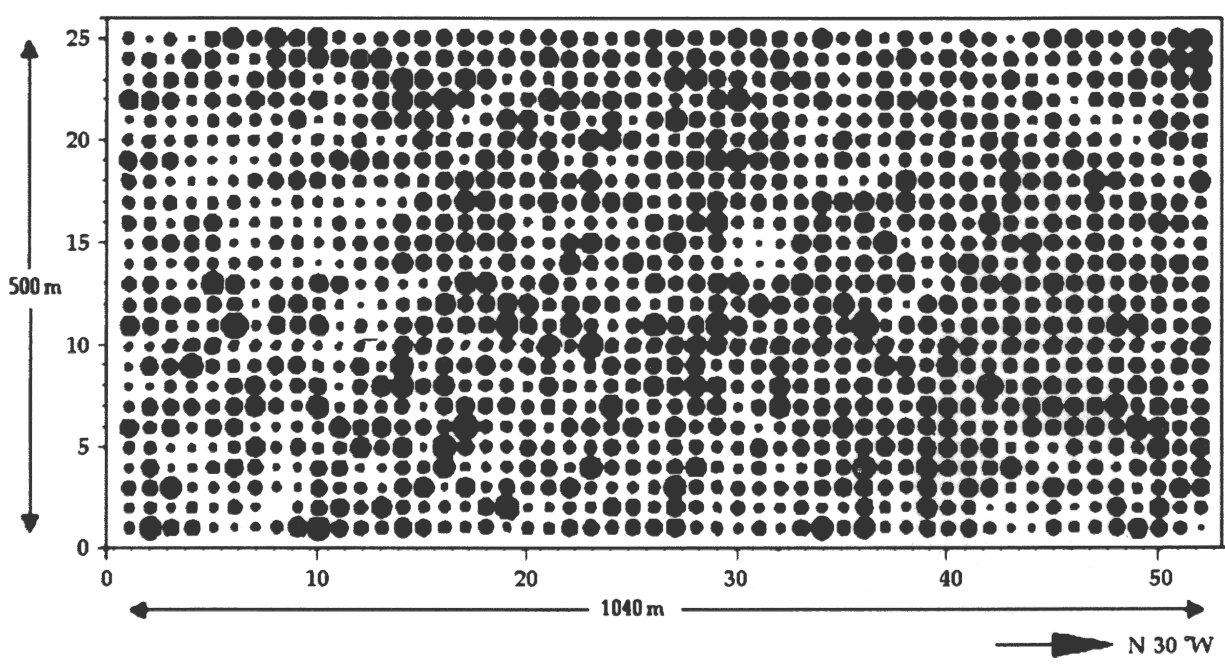

Fig. 3. Spatial pattern of aboveground biomass in the 52 ha plot. The area of a circle is proportional to stand biomass estimated in each of $1300,20 \mathrm{~m} \times 20 \mathrm{~m}$ stands. 
Table 2. Correlation coefficients between physiognomic dimensions.

\begin{tabular}{lccccc}
\hline Variables & Density & $\begin{array}{l}\text { Maximum } \\
\text { dbh }\end{array}$ & Basal area & Biomass & $\begin{array}{l}\text { No. of sub- } \\
\text { populations }\end{array}$ \\
\hline Density & 1.000 & 0.073 & 0.174 & 0.102 & 0.123 \\
Maximum dbh & & 1.000 & 0.780 & 0.831 & 0.271 \\
Basal area & & & 1.000 & 0.988 & 0.223 \\
Biomass & & & & 1.000 & 0.222 \\
No. of subpopulations & & & & & 1.000 \\
\hline
\end{tabular}

All the correlation coefficients are significant $(P<0.01)$.

pattern in biomass seemed to parallel those of the other dimensions listed in Table 1, since the dimensions in Table 1 are significantly correlated between each other (Table 2), and since biomass is calculated by incorporating dbh, tree height, and tree density (cf. Eqs (1)-(4)). Therefore, the spatial pattern of stand biomass is thought to be representative of those of the other physiognomic dimensions and is investigated in detail.

The area of the circles in Fig. 3 is proportional to stand biomass. The frequency distribution of stand biomass is also shown in Fig. 4. The largest and smallest biomass values were 1,826 ton/ha and 9 ton/ha, respectively. The mean biomass was 520 ton/ha (Fig.4), which is one of the highest estimates in Southeast Asia (cf. Yamakura et al., 1986). According to our experience in East Kalimantan in Indonesian Borneo (Yamakura et al., 1986), the biomass difference between different forest stands results from the difference of growth stages in terms of the forest growth cycle (Whitmore, 1984). Hence, small circles in Fig. 3 and smaller biomass classes in Fig. 4 correspond to the gap phase in the forest growth cycle, while large circles represent the mature phase. The mean stand biomass, 520 ton/ha, in Lambir was little greater than that of 509 ton/ha in the aforementioned forest in East Kalimantan, where the areas of gap, building, and mature phase in a 1.0 ha study plot were in the ratios 0.10:0.15:0.75 (Yamakura et al., 1986). Although the ratios of areas of three phases have not yet been determined in Lambir, it might be comparable to those in East Kalimantan.

In general, the stand biomass tends to be proportional to forest height. If we tentatively measure forest height by the possible maximum height $H^{*}$ in Eq.(1), it was $63 \mathrm{~m}$ in Lambir and $88.4 \mathrm{~m}$ in the aforementioned forest in East Kalimantan. Forest height measured by the observed maximum tree height was $61 \mathrm{~m}$ in Lambir and $70.7 \mathrm{~m}$ in East Kalimantan. However, the mean biomass in Lambir was a little greater than that in East Kalimantan, suggesting a difference in biomass density between two sites.

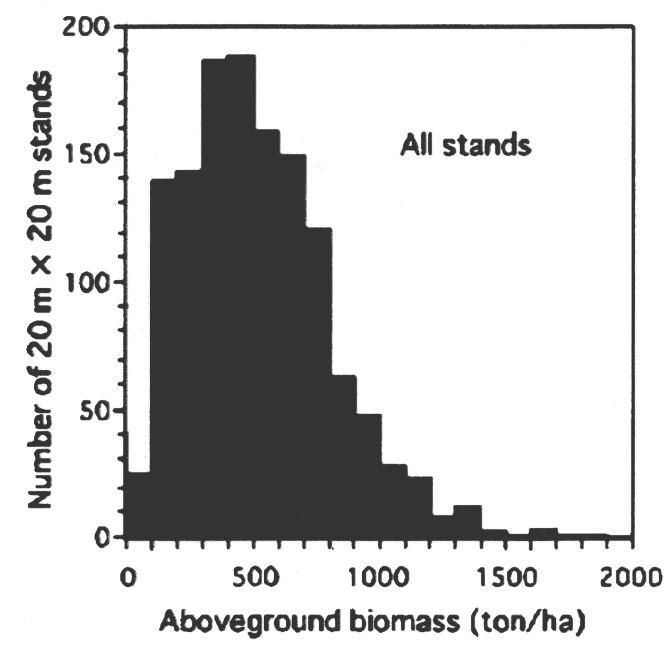

Fig. 4. Frequency distribution of aboveground biomass estimated in each of $1,30020 \mathrm{~m} \times 20 \mathrm{~m}$ stands. 
The aboveground biomass divided by forest height is designated as the biomass density or plant mass packing per unit forest space, which is defined by a product of unit land area and forest height (Ogawa, 1969). Biomass divided by forest height is more or less constant and its average is similar to or less than the physical density of the air mass (1.3 $\mathrm{kg} / \mathrm{m}^{3}$ ) (Hozumi, 1964). Biomass density tends to level off with an increase of forest height because the disturbances in natural forests due to tree falls or senescence of big trees are generally more severe in tall forests than in lower forests (Yamakura et al., 1986). Following this tendency in biomass density, mean stand biomass in our Lambir plot was thought to result from an optimum condition, which reconciles a contradiction between the limit of forest height growth and the accumulation of biomass density, and keeps stand biomass at its maximum. Thus, biomass in our Lambir rain forest is huge.

\section{Correlated changes in stand biomass and topography}

We thought that the big local variations of the physiognomic variables, such as biomass, in the plot were highly correlated with the phases in the forest growth cycle, as already described. However, biomass may also change with respect to other factors, such as

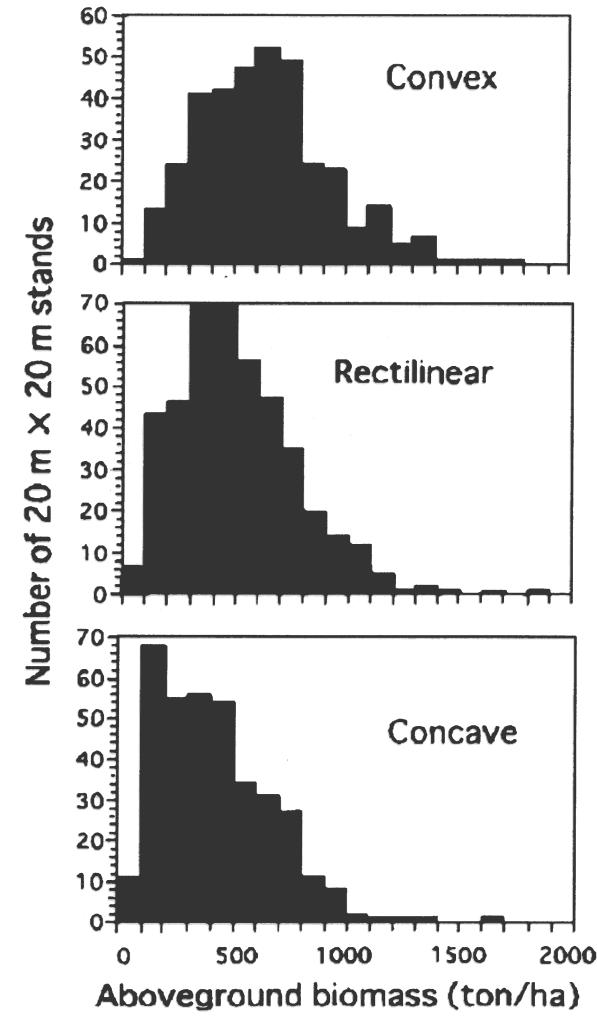

Fig. 5. Frequency distribution of aboveground biomass estimated in each of $20 \mathrm{~m} \times 20 \mathrm{~m}$ stands at three contrasting slope shapes, convex, rectilinear, and concave slopes. topographic conditions. To confirm the possibility of a dependency of biomass on topography, the 1,300 $20 \mathrm{~m} \times 20 \mathrm{~m}$ stands were classified into several groups following the stand topographic conditions, altitudes, slope angles, slope directions, and convexity indices of slopes, which were analyzed in the preceding study (Yamakura et al., 1995b). Furthermore, we categorized the topographic conditions into several classes by their respective values.

For example, the index of the convexity of slope, IC, was classified into three groups representing convex, rectilinear (or straight), and concave slopes, respectively. According to IC values in the preceding study, the respective 1,150 biomass estimates, excluding the estimates in the outermost stands where the IC was unavailable, were lumped into three IC classes. The frequency distribution of biomass estimates in respective classes of convex, rectilinear, and concave slope categories is shown in Fig. 5. Mean biomass values were 422, 508, and 640 ton/ha for concave, rectilinear, and convex slopes, respectively. The t-test suggested a significant difference $(\mathrm{P}<0.01)$ among these three mean biomass values. Thus, the biomass was correlated with IC as one of topographic variables. Besides the t-test, the ANOVA-test was also applied to confirm the dependency of biomass on IC. The result of the test supported that of the t-test. This dependency of biomass on IC was true for the other variables, tree density, maximum dbh, and basal area (Table 3). Nine of twelve ANOVA-tests for the other combinations of physiognomic and topographic variables indicated significant dependency of physiognomy on topography as sown in Table 3. Therefore, physiognomic dimensions clearly 
Tab. 3. Results of ANOVA tests for predictable changes of physiognomic dimensions with respect to topographic variables.

\begin{tabular}{lcccc}
\hline $\begin{array}{l}\text { Physiognomic } \\
\text { variables }\end{array}$ & \multicolumn{4}{c}{ Topographic variables } \\
\cline { 2 - 5 } & Altitude & Angle & Direction & Convexity index \\
\hline Density & $* *$ & $* *$ & $* *$ & $* *$ \\
Maximum dbh & $* *$ & $*$ & $*$ & $* *$ \\
Basal area & $* *$ & NS & $*$ & $* *$ \\
Biomass & $* *$ & NS & NS & $* *$ \\
No. of subpopulations & $* *$ & NS & NS & NS
\end{tabular}

The convexity index of slope stands for the definition in the preceding study (Yamakura et al., 1995a). Asterisks represent statistical significance levels, i.e. ${ }^{*}(P<0.05)$ and ** $(P<0.01)$. The symbol NS represents $P \geqq 0.05$.

depended on topography, suggesting the topographic influence on the frequency of the three growth phases, gap, building, and mature phases, in the forest growth cycle.

\section{Size structured forest stands}

The size structure of a forest stand had been represented by the frequency distribution of individual tree size, such as dbh, in forest research (Hozumi, Shinozaki, \& Tadaki, 1968; Yamakura \& Shinozaki, 1980). Following the conventional aspects in preceding researches, the frequency distribution of dbhs of individual trees is analyzed in this section.

A model of a probability density function of random variables, Weibull distribution, was first adopted to describe the frequency distribution of $\mathrm{dbh}$ in a stand, since it has a wide applicability to observed data (Japanese Standards Association, 1972). It is a non-normal continuous distribution and is favored by recent forest research (Stauffer,1979; Cao \& Burkhart, 1984; Jayaraman \& Rugmini, 1988). It is written in the form,

$$
\begin{aligned}
& f(x)=\frac{m}{\alpha}(x-\xi)^{m-1} \exp \left[-\frac{(x-\xi)^{m}}{\alpha}\right], \\
& F(x)=1-\exp \left[-\frac{(x-\xi)^{m}}{\alpha}\right]
\end{aligned}
$$

where $x$ is dbh in $\mathrm{cm}, f(x)$ is the probability density function of $x, F(x)$ is the distribution function of $x$, and the other symbols, $m, \alpha$, and $\xi$, are coefficients specific to a stand. The coefficient $m$ gives determinative effects on the shape of $f(x)$ in the $x$ vs. $f(x)$ diagram. The coefficient $a$ is concerned with the scaling of $x$. The other coefficient $\xi$ is available for truncating $x$. In applying $f(x)$ of Eq. (5) to observed data, the coefficient $\xi$ was assumed to be $1.0 \mathrm{~cm}$ because the minimum dbh was $1.0 \mathrm{~cm}$ in our forest inventory. The estimation of the coefficient $m$ of Eqs. (5) and (6) was done by using the popular statistical method based on the following definitional equation of the coefficient of variation of $x$ (Japanese Standards Association, 1972), i.e.

$$
C V[x]=\frac{D[x]}{E[x]}=\frac{\sqrt{\Gamma\left(\frac{2}{m}+1\right)-\Gamma^{2}\left(\frac{1}{m}+1\right)}}{\Gamma\left(\frac{1}{m}+1\right)},
$$

where, $C V[x]$ is the coefficient of variation, $D[x]$ is the standard deviation of $x, E[x]$ is the mean of $x$, and the symbol $\Gamma$ denotes the gamma function. After estimating the coefficient $m$, the other coefficient $\alpha$, was estimated by the equation (Japanese Standards Association, 1972), 
Fig. 6. Example of frequency distribution of $\mathrm{dbh}$ in a sample stand of $20 \mathrm{~m} \mathrm{X}$ $20 \mathrm{~m}$. Bars represent observed frequencies, while a smooth curve stands for frequencies expected from the Weibull distribution.
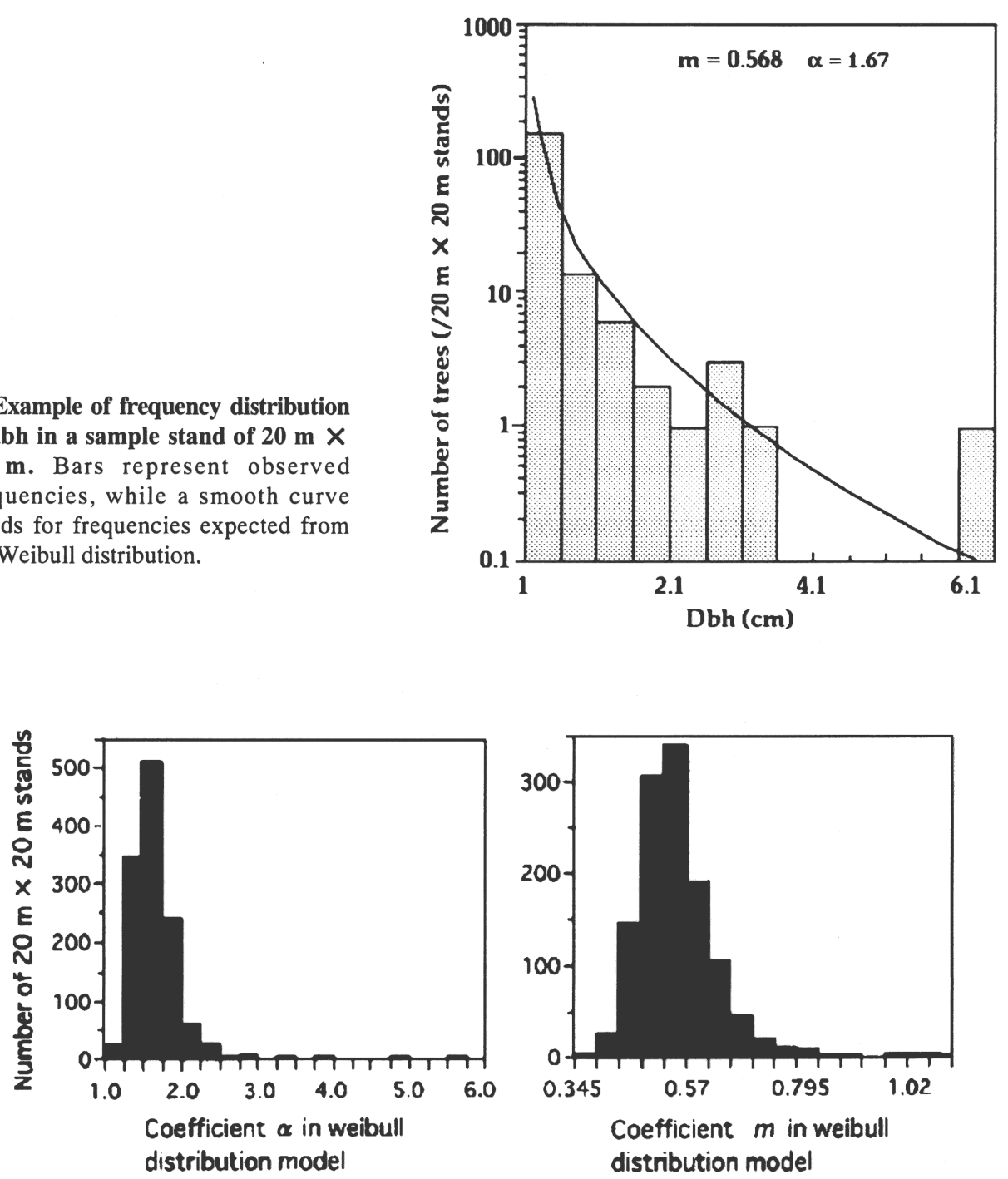

Fig.7. Frequency distribution of coefficients, $\alpha$ and $m$, of Weibull distribution, estimated for the frequency distribution of $\mathrm{dbh}$ in respective $20 \mathrm{~m} \times 20 \mathrm{~m}$ stands.

$$
\alpha=\frac{1}{N^{*}} \sum_{i=1}^{N^{*}} x_{i}^{m}
$$

where $N^{*}$ stands for the number of samples per stand, the subscript $i$ stands for identification number of individual trees, and the symbol $\Sigma$ denotes a summation of $x$. An example of the fit of the Weibull distribution is shown in Fig. 6, by using the estimated coefficients. The chi-square test supports the applicability of the distribution function to the observed data in all the stands, when a dbh class interval of $5.0 \mathrm{~cm}$ is used in the test. The frequency distribution of the estimated coefficients is given in Fig. 7. The coefficient $\alpha$ increased with an increase of the coefficient $m$. Here, it is noteworthy that most estimated $m$ values were less than 1.0, excluding four estimates. The four estimates of $m$ were 


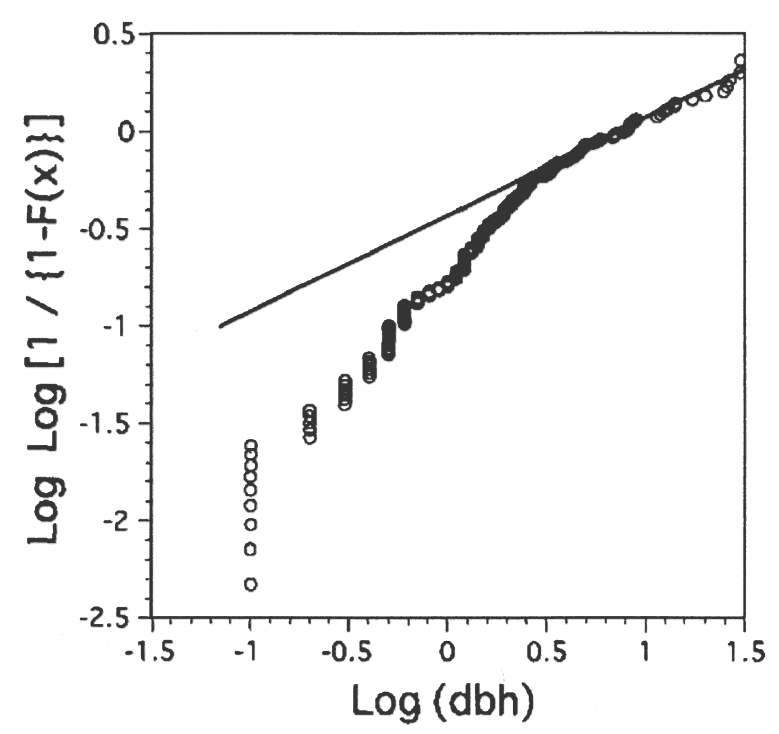

Fig.8. Probability paper of Weibull distribution. A straight line stands for an expected trajectory calculated by the Weibull distribution whose two coefficients are estimated by the conventional statistical methods. Circles show observed values. Several segmental linear lines are necessary to cover the whole range of the observed trajectory. For details, see the text.

greater than 1.0 but never exceeded 1.2. When $m=1.0$, the Weibull distribution gives the exponential distribution. When $m<1.0$, the Weibull distribution can express a highly skewed L-shaped frequency distribution of samples. This type of frequency distribution is monotonous in shape without having any modal sample value. Although the chi-square test suggested a good fit of the Weibull distribution to the observed dbh data, a more sensitive test was tried by using probability paper. In the case of the Weibull distribution, a numerical transformation of $x$ and $F(x), \log \log [1 /\{1-F(x)\}]$ and $\log x$, gives a probability paper (cf. Eq.(6)). If a set of data of samples follows the Weibull distribution, a trajectory of $\log \log [1 /\{1-F(x)\}]$ is linear with respect to $\log x$ in the probability paper. However, the relationship between $\log \log [1 /\{1-F(x)\}]$ and $\log x$ was not linear in the probability paper and was better approximated by several segmental linear lines (Fig. 8), which suggested a more complex size structure with discrete subpopulations. The occurrence of the subpopulations might reflect a mosaic of stands each differing in its history.

\section{Stratification of individuals}

If the discrete subpopulations are included in a whole sample population, the further understanding of the sample population is given by discerning respective subpopulations, which together constitute the whole sample population. It follows that the stratification of trees in a stand into subpopulations is helpful for the better recognition of our study forest. Following this idea, the stratification of individual trees was carried out as described below.

For stratifying the individuals, we adopted the probability paper of the exponential distribution of $\mathrm{dbh}$, since most of the estimates of the coefficient $m$ of Weibull distribution in Eq. (5) were smaller than 1.0 and suggested a monotonous frequency curve with respect to $\mathrm{dbh}$, and since the exponential distribution is easy to handle. We write the exponential distribution of $\mathrm{dbh}$ in the form,

$$
\begin{aligned}
& f(x)=\frac{1}{\lambda} \exp \left(-\frac{x}{\lambda}\right) \\
& F(x)=1-\exp \left(-\frac{x}{\lambda}\right)
\end{aligned}
$$


Fig.9. Probability paper of the exponential distribution of $\mathrm{dbh}$. The horizontal axis represents an ordered ranking of individual trees arranged in the descending order of $\mathrm{dbh}$. The vertical axis is dbh corresponding to a given individual rank. The segmental lines are thought to express partial populations or subpopulations consisting a whole sample population per stand of $20 \mathrm{~m}$ $\times 20 \mathrm{~m}$. The arrows show boundaries between subpopulations. Five subpopulations are recognizable in this example stand. For details, see the text.

Fig. 10. Number of subpopulations per stand with respect to stand altitudes; low, <170 m; medium, $170 \leqq$ and $<200 \mathrm{~m}$; high $200 \mathrm{~m}<$. Vertical bars and boxes indicate \pm $\mathrm{SD}$ and $\pm \mathrm{SE}$, respectively. Figures indicate the mean number of subpopulations. The differences between three altitude classes are significant $(P<0.01)$ in the
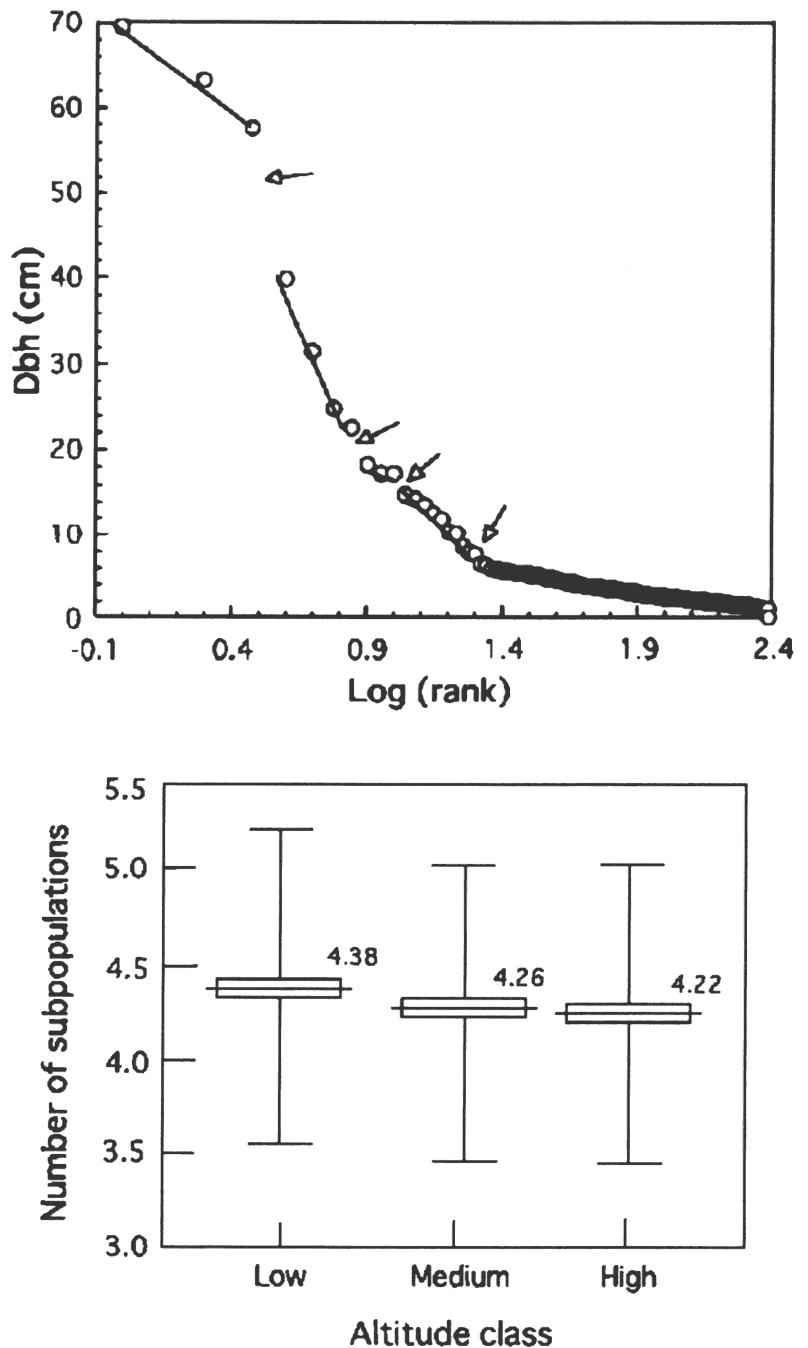

where the symbols, $x, f(x)$, and $F(x)$, are the same with those of Eqs. (5) and (6). The symbol $\lambda$ denotes the coefficient specific to a stand and coincides with the mean of $x$.

Here, we introduce the ordered ranking of individual trees arranged in a descending order of their dbh and tentatively denote it by $N(x)$. The $N(x)$ is expressed by the equation (Hozumi \& Shinozaki, 1970; Hozumi, 1975),

$$
\begin{aligned}
& N(x)=N^{*} \int_{x}^{\infty} f(x) d x=N^{*} \exp [-x / \lambda] \\
& \text { or } \\
& x=\lambda \log N^{*}-\lambda \log N(x),
\end{aligned}
$$

where $N^{*}$ is the total number of individuals of the stand. Eq.(11) offers a basis of the probability paper of the exponential distribution. It follows that the $x$ vs. $\log N(x)$ relation is one of expressions of the probability paper for the exponential distribution (Fig. 9). The $x$ vs. $\log N(x)$ relation was graphically drawn for each of the 1,300 stands, as shown in Fig. 9. The several segmental linear lines were necessary to approximate the observed $x$ vs. $\log N(x)$ relation. Each segmental line was thought to 


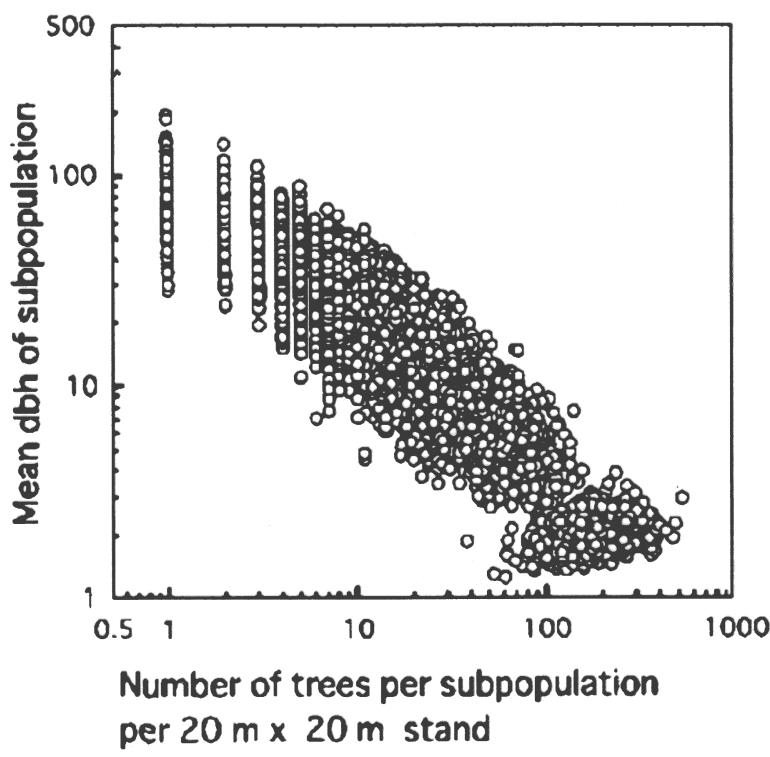

Fig. 11. Dependency of mean dbh on tree density per subpopulation per stand.

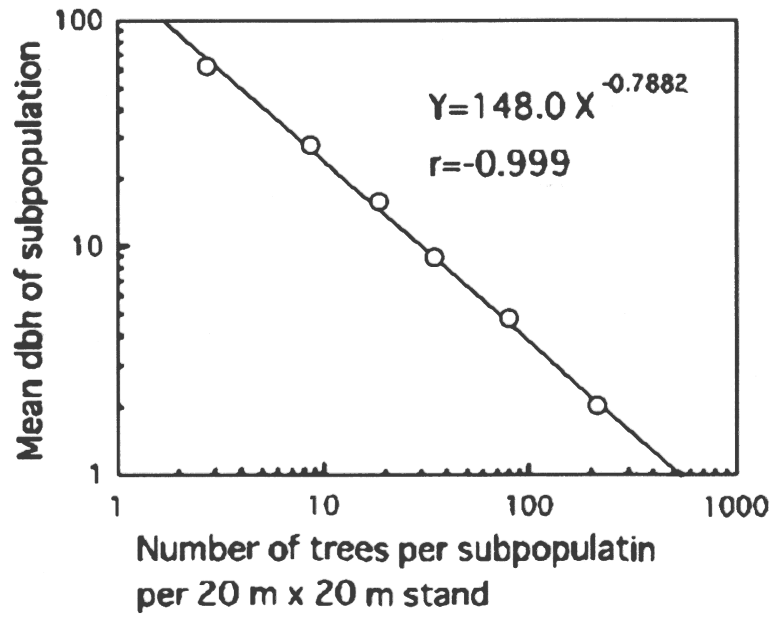

Fig.12. Linear trajectory between logarithmic values of two variables, mean dbh and tree density, in a subpopulation. All the observed values in Fig. 11 were lumped into six groups by tree density intervals, 1-5, 6-12, 13-25, 26-47, 44-144, and $145-524$ per 20 $\mathrm{m} \times 20 \mathrm{~m}$ stand, which were chosen so as to evenly distribute samples among the groups. The number of samples in the density groups are $1031,850,928,795,897$, and 1075 , respectively. An open circle stands for the observed mean value of samples in each of the six density groups.

express a subpopulation. The number of stratified subpopulations per stand counted for 1,300 stands was in a range between two and seven. The mean was 4.3 per stand with a standard deviation of 0.82 , implying the existence of a multi-layer system of the tropical rain forest as suggested by Richards $(1952,1983)$. The variation of this quantity among stands might reflect the phases of the forest growth cycle. Furthermore, the number of subpopulations per stand tended to increase with a decrease in altitude (Fig. 10). This tendency in the number of subpopulations was consistent and confirmed by the ANOVA-test (Table 3). However, its correspondence to slope angles, directions, and IC values was denied by the ANOVA-test (Table 3). Using the results of the stratification of individuals, the mean $\mathrm{dbh}$ was calculated for each of 5,576 subpopulations discerned by stratification. The mean values thus obtained decreased with an increase of tree density per subpopulation (Fig. 11 \& 12). The trajectory of mean dbh to tree density per subpopulation in Fig. 11 might be written in the form,

$$
\frac{1}{D_{i}}=\frac{\rho_{i}}{K}+\frac{1}{L}
$$


where the symbol $i$ is an identification number of subpopulations, $D_{i}$ is mean dbh per subpopulation, $\rho_{\iota}$ is tree density per subpopulation, and $K$ and $L$ are coefficients specific to the data. However, when we calculated the average of $D_{i}$ and $\rho_{i}$ by classifying the data into six groups (Fig. 12), a linear line for two variables became clear, i.e.

$$
\log D_{i}=2.170-0.7882 \log \rho_{i} \quad
$$

The absolute value of the line gradient, 0.7882 , is rather greater than 0.5 expected by the physical dimensions of two variables (Yamakura, 1989), implying severe suppression of smaller trees by the larger trees. The density dependency of plant growth is well known in forestry and plant ecology and was reported by several studies of single-story forests composed of single species (Reineke, 1933; Yoda et al., 1963; Hozumi \& Shinozaki, 1970; Harper, 1977; White,1981) and natural forest communities with superimposed multi-stories consisting of various species (Yamakura, 1989). Although the subpopulations in the present study might not strictly correspond to the stories or layers in terms of forest stratification conceptualized by Richards (1952), the dependency of mean dbh upon tree density in subpopulations supports the facts so far found in the preceding studies.

\section{DISCUSSION}

The forest stature of our rain forest at Lambir was the highest among the three forests at Barro Colorado Island (BCI) in Panama, Pasoh in West Malaysia, and Lambir in Sarawak, though the difference between Pasoh and Lambir was insignificant owing to the large dispersion of observed data in the dbh vs. tree height relation. The forest structure at BCI was the lowest among three sites and apparently highly affected by the long dry spells. The largest forest stature in Lambir suggested that the favorable ever-wet climatic conditions without severe dry spells throughout the year is indispensable for tree height growth in tropical rain forest in the world (Ashton \& Hall, 1992). Hence, a biological principle, no life without water, could clearly explain the differences in forest height among three sites. It follows that the forest at BCI might experience a severe climatic sieve in terms of forest architecture. If the climatic moisture condition, especially rainfall, is favorable enough to allow the moist forest in all the localities inside Sarawak, the forest height differences between rain forests in Sarawak should be explained by factors other than rainfall, i.e. topographic and edaphic influences on periodicity of wetness (Richards, 1952; Ashton \& Hall, 1992).

Mean stand biomass calculated for respective $1300,20 \mathrm{~m} \times 20 \mathrm{~m}$ stands seemed to arrive at the climax in its development, which is attained by reconciling the antagonistic requirements from forest height growth and biomass density growth. The mean aboveground biomass values calculated by Brown et al. (1989) for undisturbed tropical rain forests in three continents were 170 ton/ha in America, 260 ton/ha in Africa, and 214 ton/ha in Asia. These values were far smaller than biomass at Lambir, 520 ton/ha, since the biomass values estimated by Brown et al. included the estimates from the forests in dryer climatic conditions. An implication from the differences between the estimates is that the logging of Sarawak rain forest contributes to the large loss of tropical forest biomass. The Biomass differences among BCI, Pasoh, and Lambir were obscure, since biomass has never been calculated in 50 ha plots at $\mathrm{BCI}$ and Pasoh.

In addition to biomass, other physiognomic dimensions were also handled in the present study. All the dimensions including biomass exhibited large local variability within the plot. The variation of these dimensions was predictable with respect to topography. The determinant effect of topography on 
the forest structure was not consistently investigated in preceding studies so far carried out in tropical rain forests, since the topographic conditions were rather difficult in their quantification and evaluation and since the large research plot is necessary for getting meaningful topography data. The effects of topography was obscured by some other factors, such as soils, in the preceding studies (eg. Ashton, 1964; Ashton \& Hall,1992) because the topography is inevitably combined with other factors (solar radiation, soil water, wind, rainfall, disturbance, etc.) and represents a mixed factor consisting of the different but mutually related aspects, altitude etc. (Yamakura et al., 1995b). The predictable changes of the physiognomic dimensions with respect to topography suggest that forest architecture is adapted to environmental conditions and reduces the random or chance occurrence of the architecture in a given land area, thereby favoring by niche theory (Hutchinson, 1957) or equilibrium hypothesis rather than the non-equilibrium hypothesis (Hubbell \& Foster, 1986), though floristic composition can be independent from forest architecture.

All the individual trees in respective $20 \mathrm{~m} \times 20 \mathrm{~m}$ stands were stratified into several subpopulations by a probability paper of the exponential distribution of dbh. The stratification of individuals with respect to tree height is one of the phenomena included in the concept of forest stratification emphasized by Richards (1952) and was numerically analyzed by several studies (Hozumi, 1975; Yamakura, 1987). According to our former experience (Yamakura, 1989), the results of the stratification of individuals by dbh corresponded well to those of stratification by tree height. Hence, the stratification of individuals by dbh in the present study seemed to be comparable to that by tree height. However, the difference between stratification by dbh and stratification by tree height should also be examined in studies at Lambir, in the future.

Although it remains unclear that whether the subpopulations recognized in the present study corresponded to the layers in terms of Richards, the number of subpopulations varied between stands. This variation in classified subpopulations might suggest the dependency of forest stratification on the topography as well as the phase of the forest growth cycle (Oldeman, 1978). To confirm the occurrence of subpopulations in the present study, demographic data of the birth, growth, and death of trees are necessary (Yamakura, 1987). For example, the exponential distribution of dbh can be easily transformed into a corresponding distribution function of any one of the parameters of tree growth, such as relative growth rates of dbh in Malthusian dbh growth, when a growth function of dbh is explicitly given. All the parameters of individual tree growth should satisfy the conditions limited by the exponential distribution or distribution function. Therefore, the derived distribution function of relative growth rates of dbh will offer a standard scale for evaluating the possibility of forest stratification by using observed dbh growth data.

The mean dbh per subpopulation followed the power law system studied by Yoda et al. (1963). The system is well known and recognized as a phenomenon, which represents an adjustment of plants to the overcrowding or competition for living space between individuals. Therefore, the density dependency in subpopulation dbh growth harmonizes with the equilibrium hypothesis, as well as the stratification of individuals. The non-equilibrium hypothesis proposed by Hubbell and Foster (1986) is nevertheless one of the most stimulating theories for the explanation of working mechanisms of tropical biodiversity. To test the applicability of the theory to Lambir rain forest, the finalization of our species data are necessary at the earliest opportunity. Concerning this, some forest architectural aspects of species will be discussed by using a part of the species data so far compiled, though the conclusion of the discussion will be inevitably tentative and hypothetical (Yamakura et al., 1995c). 


\section{CONCLUSION}

The forest height differences between three research sites, BCI, Pasoh, and Lambir, corresponded well to the relative frequency of dry spells in rainfall rhythms at the three sites. It implies a severe climatic sieve at BCI. The physiognomic dimensions such as biomass were significantly correlated with the complex topography at Lambir, suggesting topographic influence on the occurrence of respective growth phases in the forest growth cycle at Lambir. Furthermore, the forest was highly size structured and was recognized as a mosaic of $1,300,20 \mathrm{~m} \times 20 \mathrm{~m}$ stands with different stratified subpopulations, which were constrained by the density dependency of mean dbh growth. These results clarify the huge and complex architecture of the Lambir rain forest, and seem to support the equilibrium hypothesis rather than non-equilibrium hypothesis as the working mechanisms of the biodiversity in tropical rain forest, though floristic composition can be conceptually free from any constraints of physiognomic dimensions.

ACKNOWLEDGEMENTS We wish to thank profoundly the State Government and Forest Department of Sarawak for their helpful support. Our thanks are also due to Datuk Leo Chai, the Director of Forests, Forest Department of Sarawak, Emeritus Professors Dr. Saburo Tamura and Dr. Yasuo Takai, University of Tokyo for their attentive suggestions and long term support. We are particularly indebted to staffs at the Silviculture Research Office, Sibu, Sarawak for their friendly collaboration and extraordinary contribution to the establishment of the research plot. We owe much to Mr. Abang Abdul Hamid, the Entomologist, Forest Department of Sarawak and Dr. James V. LaFrankie, CTFS, Smithsonian Tropical Research Institute, USA for their helpful collaboration. This study was supported in part by Grant-in-Aids for International Scientific Research (Nos 02041071 and 06041094) from the Ministry of Education, Science and Culture, Japan, and a Grant-in-Aid from Nippon Life Insurance Foundation.

\section{REFERENCES}

Ashton, P. S. 1964. Ecological Studies in the Mixed Dipterocarp Forests of Brunei State. 73 pp. Oxford Forestry Memoirs 25. Oxford Univ., Oxford.

— \& Hall, P. 1992. Comparisons of structure among mixed dipterocarp forests of north Borneo. $J$. Ecol. 80: 459-481.

Brown, S., Gillespie, A. J. R. \& Lugo, A. E. 1989. Biomass estimation methods for tropical forests with application to forest inventory data. For. Sci. 35: 881-902.

Cao, Q. V. \& Burkhart, H. E. 1984. A segmental distribution approach for modeling diameter frequency data. For. Sci. 30: 129-137.

Chai, E. O. K., Lee, H. S. \& Yamakura, T. 1994. Preliminary Results of the 52 Hectare Long Term Ecological Research Plot at Lambir National Park, Miri, Sarawak, Malaysia, 97 pp. Silviculture Research Office, Forest Department Sarawak, Sibu.

Department of Civil Aviation \& Meteorological Services, British Borneo Territories. 1961. Rainfall Statistics of the British Borneo Territories (Sarawak-Brunei-North Borneo); Period 1896-1957, 173 pp. Department of Civil Aviation \& Meteorological Services, British Borneo Territories.

Harper, J. L. 1977. Population Biology of Plants, 22+892 pp. Academic Press, London.

Hozumi, K. 1964. Mathematical models in plant ecology. Read at the Symp., 11th Ann. Meet., Jpn. Ecol. Soc., Sendai. 
1975. Studies on the frequency distribution of the weight of individual trees in a forest stand.

V. The M-w diagram. Jpn. J. Ecol. 25: 123-131.

\& Shinozaki, K. 1970. Studies on the frequency distribution of the weight of individual trees in a forest stand.II. Exponential distribution. Jpn. J. Ecol. 20: 1-9.

——— — Tadaki, Y. 1968. Studies on the frequency distribution of the weight of individual trees in a forest stand. I. A new approach toward the analysis of the distribution function and the 3/2th power distribution. Jpn. J. Ecol. 18: 10-20.

Hubbell, S. P. \& Foster, R. B. 1983. Diversity of canopy trees in a Neotropical forest and implications for conservation. In: Sutton, S. L., Whitmore, T. C. \& Chadwick A. C., eds., Topical Rain Forest: Ecology and Management, 25-41. Blackwell Sci. Publ., Oxford.

— 1 1986. Biology, chance, and history and the structure of tropical rain forest tree communities. In: Diamond, M. J. \& Case, T. J., eds., Community Ecology, 314-329. Blackwell Sci. Publ., Oxford.

Hutchinson, G. E. 1957. Concluding remarks. Cold Springer Harbor Symp. Quant. Biol. 22: 415-427.

Japanese Standards Association, 1972. Statistical Tables and Formulas with Computer Applications, 451+266 pp. Japanese Standards Association, Tokyo. (In Japanese).

Jayaraman, K. \& Rugmini, P. 1988. Diameter distributions for even-aged teak. Indian J. For. 11: 145147.

Katagiri, S. 1992. Soil classification. In: Shidei, T. \& Kira, T., supervisors, Yamada, I. \& Yamakura, T., eds., Think About Tropical Rain Forest, 150-179. Jinbun Syoin, Kyoto (in Japanese).

Kato, R., Tadaki, Y. \& Ogawa, H. 1978. Plant biomass and growth increment studies in Pasoh forest. Malay. Nat. J. 30: 211-224.

Kira, T. 1978. Community architecture and organic matter dynamics in tropical lowland rain forests of Southeast Asia with special reference to Pasoh Forest, West Malaysia. In:Tomlinson, P. B. \& Zimmerman, M. H., eds., Tropical Trees as Living Systems, 561-590. Cambridge Univ. Press, Cambridge.

\& Ogawa, H. 1971. Assessment of primary production in tropical and equatorial forests. In: Duvigneaud, ed., Production of Forest Ecosystems: Proc. Brussels Symp. Organized by UNESCO \& IBP (27-31 Oct. 1969), 309-321. UNESCO, Paris.

Kurashima, A., Ochiai, M., Aoki, S., Tsuchiya, I. \& Aruga, A. 1964. Climate of Asia, 577 pp. Kokin Shoin, Tokyo. (In Japanese).

Manokaran, N., Lafrankie, J. V., Kochumen, K. M., Quah, E. S., Klahn, J. E., Ashton, P. S. \& Hubbell, S. P. 1990. Methodology for the 50-ha Research Plot at Pasoh Forest Reserve. Research Pamphlet 104, 69 pp. Forest Research Institute, Malaysia.

Ogawa, H. 1969. A new approach toward the classification of forest formations by using the relation between stem diameter and tree height. In: Kira, T., ed., Studies on the Methods for Assessing Primary Production of Forests: Progress Report for JIBP 1966, 3-17. Osaka City Univ., Osaka. (Mimeogr., in Japanese).

— \& Kira, T. 1977. Methods of estimating forest biomass. In: Shidei, T. \& Kira, T. eds., Primary Productivity of Japanese Forests: JIBP Synthesis 16, 15-25. Univ. Tokyo Press,

— Yoda, K., Ogino, K. \& Kira, T. 1965. Comparative ecological studies on three main types of forest vegetation in Thailand. II. Plant biomass. Nature \& Life in Southeast Asia 4 (Kira, T \& Iwata, K. eds.): 49-80.

Oldeman, A. A. 1978. Architecture and energy exchange of dicotyledonous trees in the forest. In: Tomlinson, P. B. \& Zimmerman, M. H., eds., Tropical Trees as Living Systems, 535-560. 
Cambridge Univ. Press, Cambridge.

Reineke, L. H. 1933. Perfecting a stand-density index for even-aged forests. J. Agr. Res. 46: 627-638.

Research Group on Forest Productivity. 1960. Studies on the Productivity of the Forest. I. Essential Needle Leaved Forests of Hokkaido, 3+100 pp. Kokusaku Pulp Co. Ltd., Tokyo. (In Japanese).

Richards, P. W. 1952. The Tropical Rain Forest (reprinted with corrections 1979), 450 pp. Cambridge Univ. Press, Cambridge.

1983. The three dimensional structure of tropical rain forest. In: Sutton, S. L., Whitmore, T. C. \& Chadwick, A. C., eds., Topical Rain Forest: Ecology and Management, 3-10. Blackwell Sci. Publ., Oxford.

Stauffer, H. B. 1979. A derivation for the Weibull distribution. J. Theor. Biol. 81: 55-64.

White, J. 1981. The allometric interpretation of the self-thinning rule. J. Theor. Biol. 89: 475-500.

Windsor, D. M. 1990. Climate and Moisture Variability in a Tropical Forest: Long Term Records from Barro Colorado Island, Panama, 145 pp. Smithsonian Institution Press, Washington.

Whitmore, T. C. 1984. Tropical Rain Forests of the Far East, 352 pp. Clarendon Press, Oxford.

Yamakura, T. 1987. An empirical approach to the analysis of forest stratification. I. Proposed graphical method derived by using an empirical distribution function. Bot. Mag. Tokyo 100: 109128.

1989. A further analysis of the quasi-1/2 power law of tree height in stratified forest communities. Bot. Mag. Tokyo 102: 115-131.

— \& Shinozaki, K. 1980: Frequency distribution of individual weight, stem diameter, and height in plants stands. I. Proposed new distribution density functions derived by using the finite difference method. Jpn. J. Ecol. 30: 307-321.

_ Sahunalu, P. \& Karyono. 1989. A preliminary study of changes in forest stratification along environmental gradients in Southeast Asia. Ecol. Res. 4: 99-116.

—, Hagihara, A., Sukardjo, S., Ogawa, H., 1986. Aboveground biomass of tropical rain forest stands in Indonesian Borneo. Vegetatio 68: 71-82.

— Yamada, I., Inoue, T. \& Ogino, K. 1995a. A long-term and large-scale research of the Lambir rain forest in Sarawak: progress and conceptual background of Japanese activities. Tropics 4: 259276.

—, Kanzaki, M., Itoh, A., Ohkubo, T., Ogino, K., Chai, E. O. K., Lee, H. S. \& Ashton, P. S. 1995b. Topographys of a large-scale research plot established within a tropical rain forest at Lambir, Sarawak. Tropics 5: 41-56.

—, Kanzaki, M., Itoh, A., Ohkubo, T., Ogino, K., Chai, E. O. K., Lee, H. S. \& Ashton, P. S. 1995c. Correlated changes in topography and forest architecture within a rain forest at Lambir in Sarawak. In: Abstracts of International Symposium "Measuring and Monitoring Forest Biological Diversity: the International Network of Biodiversity Plots (23-25 May 1995)”, 84. Smithsonian Institution, Washington.

Yoda, K. \& Kira, T. 1982. Accumulation of organic matter, carbon,nitrogen and other nutrient elements in the soils of a lowland rain forest at Pasoh, Peninsular Malaysia. Jpn. J. Ecol. 32: 275291.

— - Ogawa, H. \& Hozumi, K. 1963. Self-thinning in overcrowded pure stands under cultivated and natural conditions (Intraspecific competition among higher plants. XI). J. Biol. Osaka City Univ. 14: 107-129.

Received February 16, 1995

Accepted February 10, 1996 
山倉拓夫, 神崎 護, 伊東 明, 大久保達弘, 荻野和彦, E. CHAI O. K., H. S. LEE, P.S. ASHTONサラワク州ランビル熱帯雨林の森林構造の地形依存性

東マレーシア・サラワク州・ランビル国立公園の混合フタバガキ林に設定した 52 ヘクタール大面積森林調 査区のデー夕を用いて，熱帯雨林の森林構造を解析し，その地形依存性を論じた。

胸高直径〜樹高関係に逆数式型の樹高曲線を当てはめ, 林分上限樹高を求めると, $63 \mathrm{~m}$ の推定值を得た。 この值は, 既に大面積森林調査区が設定されている半島部マレーシアのパソー $(61 \mathrm{~m})$ 及びパナマのバロ・ コロラド島 (42.8 m) の熱帯雨林で得られた值よりも大きかった。3 調査区の樹高の違いは, 降雨パターン における乾燥期間の長さと良く対応し, ランビルの森の巨大な構造が好適な水条件にあることを示唆した。 樹高発達と対応して, 地上部現存量は大きく, $520 \mathrm{t} /$ ha の推定值が得られた。

調査区全体を 1300 個の $20 \mathrm{~m} \times 20 \mathrm{~m}$ のスタンドに分け, 各スタンド毎に立木密度, 最大胸高直径, 胸 高断面積合計, 地上部現存量, 部分集団の数を求めた。これらの諸量はいずれも森林の相観と関わる変量 である。部分集団の数の推定には, 胸高直径が指数分布することを仮定し, 指数確率紙を用いた。立木密 度以外の 5 変量の地形依存性を分散分析の手法によって検定すると, 5 変量が地形と対応して変化し, 地 形方向での予測性の高いことが明らかとなった。森林構造の地形依存性の解析は, 断片的なものを除いて, これまでの熱帯雨林研究で試みられたことはなかった。その理由として, 解析に十分な量の地形デー夕を 得るためには, 困難の多い大面積調査区が必要であったことがあげられる。森林構造は森林の発達サイク ルに依存して変化するが, 構造の地形依存性は, 地形とは独立であると従来考えられてきた発達サイクル という構造形成過程でさえも, 地形に強く依存することを意味した。このような構造の地形依存性は, 構 造が環境に適応的であり, 環境の持つ場の力が構造形成過程における確率的浮動を減少させることを示唆 した。

指数確率紙を用いて行ったスタンドの部分集団推定資料を用いて, 部分集団の立木密度と平均樹高を求 め, 両者の関係を調べた。部分集団の平均樹高は立木密度のべき乗に反比例して減少し, 明らかな密度依 存性が認められた。

これまで明らかとなった湿潤な環境と対応した巨大な構造, 構造構成変量の予測性の高い地形依存性, 部分集団で認められる平均個体サイズの密度依存性の現象は, 群集多様性維持機構の説明仮説としての二 ッチ説に有利な結果となった。但し, 森林構造は種組成とは理論的には独立にあり得るので, 二ッチ説と 非ニッチ説の検証には近々整備が完了する種組成データの解析が必要である。 